\title{
ISSUES ON VULNERABILITY OF PASSENGER
} TRANSPORTATION SYSTEM

\section{ZAGADNIENIE PODATNOŚCI NA ZAGROŻENIA SYSTEMU TRANSPORTU PASAŻERSKIEGO}

\author{
Agnieszka Tubis, Sylwia Werbińska-Wojciechowska \\ Wroclaw University of Technology \\ agnieszka.tubis@pwr.edu.pl,sylwia.werbinska@pwr.edu.pl
}

\begin{abstract}
In the presented paper, authors focus on the issues connected with passenger transportation system vulnerability assessment. Following this, in the article the main transportation system vulnerability definitions are discussed. Later, there is presented the comprehensive literature review connected with assessment methods used in the analysed research area. This gives the possibility to define the public transportation system's vulnerability assessment as an element of process controlling performed by a carrier. Article ends with some conclusions and directions for future research.
\end{abstract}

Keywords: transportation system, vulnerability, process

Streszczenie: W artykule autorzy skupili się na zagadnieniach zwiazanych z ocena podatności na zagrożenia systemu transportu pasażerskiego. W zwiazku z tym, $w$ artykule podstawowe definicje podatności na zagrożenia systemu transportowego zostały przedyskutowane. Następnie, przedstawiono przegląd literatury obejmujacy metody oceny wykorzystywane $w$ analizowanym obszarze badawczym. To pozwolito na zdefiniowanie oceny podatności na zagrożenia dla systemu transportu publicznego jako elementu controllingu procesowego realizowanego u przewoźnika. Artykut kończy podsumowanie oraz wytyczne obejmujace kierunki dalszych badań.

Stowa kluczowe: system transportowy, podatność na zagrożenia, proces 


\section{ISSUES ON VULNERABILITY OF PASSENGER TRANSPORTATION SYSTEM}

\section{Introduction}

Transport systems play an important role in the society, supporting the performance of a modern economy and carrying out transport services for a wide range of passengers $[5,15,22]$. However, these systems are exposed to some unwanted events such as the appearance of disturbances as a result of random events occurrence (e.g. natural disasters), technical objects degradation process, changes in demand, climate change, or threats of terrorism [23]. These events increase the system vulnerability, which may lead to the appearance of negative consequences for people and organizations in terms of economic, safety and health [12]. Currently, the level of society dependence on a reliable transport service performance grows, so issues such as susceptibility to damage or risk management are gaining in importance (e.g. [2, 12, 14, 22]). In the light of the idea of sustainable transport, where the transport system should be characterized by the availability, quality and safety of offered services, and friendliness to the environment, properly conducted risk analysis and vulnerability assessment are the base in the process of potential risks controlling and when taking decisions about reducing its level $[11,12]$.

Following this, in the article authors focused on the issue of vulnerability assessment of road passenger transport system. The aim of the article is to present this issue as a part of the analysis being performed in the context of process controlling, adapted to the needs of the company providing municipal transport services. As a result, in the next Section, there is provided a comprehensive overview of the literature in the area of transport systems vulnerability assessment. Then, authors focus on urban transport system vulnerability assessment problem. This allowed it to develop a classification of potential events that constitute a threat to the public transport system. The authors also presented a workflow for vulnerability assessment, carried out in accordance with the concept of controlling. The article concludes with a summary and guidelines, including directions for further research.

\section{Vulnerability of transportation systems - literature review}

Currently, there is a lot of work covering issues of technical systems (critical infrastructure, transport systems, etc.) vulnerability. At the same time, the concept of vulnerability is defined in many different ways, depending on, among others, the research area, or research methods used by the authors. In work [28], the author 
collected and presented known in the literature definitions of vulnerability, resilience and the concept of adaptation to changing conditions. Moreover, he discussed the history of the development of these concepts.

Later, the author in work [8] analysed the concept of vulnerability in terms of measurement and evaluation of performing systems risks. In turn, the authors in [12] presented three perspectives of vulnerability analysis of technical systems approach to assessing the vulnerability of the global system, assessment of vulnerabilities of the elements in the system, and analysis of system taking into account geographical location of its elements and their impact on the level of system vulnerability. The proposed model for vulnerability assessment was implemented for electrified network performance.

In the next paper [32], the authors presented the thirty-seven definition of the concept of vulnerability, depending on the research area. Moreover, a review of literature on the issue of technical systems vulnerability, including attempts to define the concept also in respect of the risk or reliability is presented e.g. in [18, $19,20,21,24,26,31,33]$.

The concept of transport systems vulnerability is investigated in the literature as a multidimensional problem, so there is no one universal definition commonly approved [13]. The first work, which presented an approach for assessing vulnerability in the area of operation of transport systems (proposing a formal basis) is [2]. The author in his work proposed a definition of the vulnerability of the road transport system as its susceptibility to incidents that may decrease road network serviceability. This definition is widely cited in the literature and is considered as to be representative for most transport modes [16].

Another approach to the definition of the vulnerability refers to a measure of an event occurrence probability and level of consequences of events/ critical elements failure (see e.g. works [7, 9, 12]). The third way of interpreting the definition of transport system vulnerability compares it to the so-called Achilles heel [35].

Table 1 presents chosen definitions of transportation system vulnerability that may be found in the recent literature. Some summary of the literature from the definition of the concept of vulnerability is proposed e.g. in [25], where the authors present a review of the literature in terms of e.g. the structure of the conducted analyses, interpretation and assessment methods or published simulation models and case studies. Moreover, in work [16], the authors discuss literature review in the area of transportation systems vulnerability and resilience assessment.

Currently, in the literature there can be found a number of methods and indicators to assess the vulnerability of transport systems - mainly transport networks (see e.g. works $[2,6,9,27,31])$. Literature reviews and analyses of used assessment methods of vulnerability analysis for network infrastructures are presented e.g. in [13, 16, 17, 29]. In [17], there is proposed classification of methods used in practice, suggesting the identification of groups including mathematical modelling, simulation models, scenario models, works based on the analysis of scenarios of 
Issues on vulnerability of passenger transportation system

Zagadnienie podatności na zagrożenia systemu transportu pasażerskiego

potential interference and using qualitative methods, or models based on the definition of strategies when the fault occurred.

Table 1. Chosen definitions of transportation system vulnerability

\begin{tabular}{|c|l|}
\hline Source & \multicolumn{1}{|c|}{ Definition } \\
\hline$[2]$ & susceptibility to rare, big things \\
\hline$[7]$ & $\begin{array}{l}\text { the probability of component } i \text { experiencing failure due to a given hazard } \\
\text { event multiplied by the sum of the direct and indirect natural hazard } \\
\text { induced consequences }\end{array}$ \\
\hline$[10]$ & $\begin{array}{l}\text { social a risk of disturbance and degradation processes in the transport } \\
\text { system }\end{array}$ \\
\hline$[22]$ & decrease due to an unwanted/troublesome event occurrence \\
\hline$[31]$ & $\begin{array}{l}\text { network node is vulnerable if loss (or substantial degradation) of a small } \\
\text { number of links significantly diminishes the accessibility of the } \\
\text { node, as measured by a standard index of accessibility }\end{array}$ \\
\hline$[34]$ & \begin{tabular}{l} 
defect or a weakness in the system that can be used by intruders \\
\hline
\end{tabular}
\end{tabular}

On the other hand, in work [29], the authors present a literature review covering the methods of transport networks disruption analysis. In contrast, the authors of [16] presented a review of the literature in the area of vulnerability and resilience of transportation systems. Authors discussed methods based on the use of graph theory, or the system approach. Based on an extensive literature review, the authors in work [13] proposed a methodology for the analysis of the vulnerability of the urban transport network in the light of the threat of earthquakes occurrence.

Later, the authors in [22] classified the methods used in the area of vulnerability analysis of transportation systems to one of two groups based on a network approach and on the topological approach.

Moreover, in the literature can be found works taking into account the dynamic nature of transport networks performance. For example, in [4], the authors proposed a model of dynamic assessment of transport network performance, taking into account the uncertainty of public transport, as traffic, capacity of vehicles, or disturbances in the implementation of transport services. The model was based on the use of graph theory and model called BuzzMezzo, used for dynamic modelling of e.g. transport tasks (dynamic transit operations and assignment model). The problem of dynamic modelling was later continued in [5].

On the other hand, in works $[1,6,35]$, which are focused on introducing certain measures of assessing the vulnerability of transport systems, authors proposed some evaluation indicators (vulnerability index), especially taking into account the approach based on the measurement of the costs and the distance between nodes in transport network. Classification of transport network vulnerability indicators was proposed in [35]. 
To sum up, currently published works in the field of transport systems vulnerability analysis and assessment are focused primarily on the study of their performance in case of occurrence of nodes disruption. There is a lack of work, which would describe the problem of assessing the vulnerability of transport systems as a part of the prediction implemented within the system of process controlling, whose task is to watch over the correctness of passenger service process performance.

\section{Transportation system vulnerability assessment issues as an element of process controlling analyses}

A very popular approach in the literature is the perceiving the transport systems vulnerability in terms of probability of risks/fault and its consequences [35]. Based on this approach, during transport networks vulnerability analysis performance, there are asked three basic questions [35]:

- Is there a weak point or geographical location which, if disrupted can cause a serious disruption of the whole system performance?

- How vulnerable is the network when its critical components will be disturbed/ fail?

- On what type of failures/disruptions transport network is vulnerable?

The answer to these questions need to determine the type of events that can potentially disrupt significantly the performance of transport system. Based on the work [2], such events for the road transport system can be classified into three groups: the events of emergency and/or with the unpredictable nature (e.g. weather, traffic accidents, damage to infrastructure and vehicles), planned events (e.g. the planned road works), and intentional events (e.g. terrorist attacks). On the other work [30], the authors defined three categories of hazard to urban communication system - failures of elements and parts of the transport system, disaster and traffic problems caused by human, and ecological threats. In contrast, the authors of [16] proposed the division of disruptions in the transport system in terms of internal/external disruption vs. accidental/intentional disruption.

The focus of the authors is to use the assessment of vulnerability for the public transport system in large cities in Poland. This evaluation should be a part of the procedure performed within the process controlling being implemented with the transport carrier. On the basis of this procedure, controller should be able to provide comprehensive information to the managers about possible threats, their impact on the company and should prepare proposals for scenarios in case of selected threats occurrence. Analytical procedure should take place in accordance with the diagram shown in Figure 1.

The main objective is the identification of the types of disturbances, for which the transport network is vulnerable. 
Issues on vulnerability of passenger transportation system Zagadnienie podatności na zagrożenia systemu transportu pasażerskiego

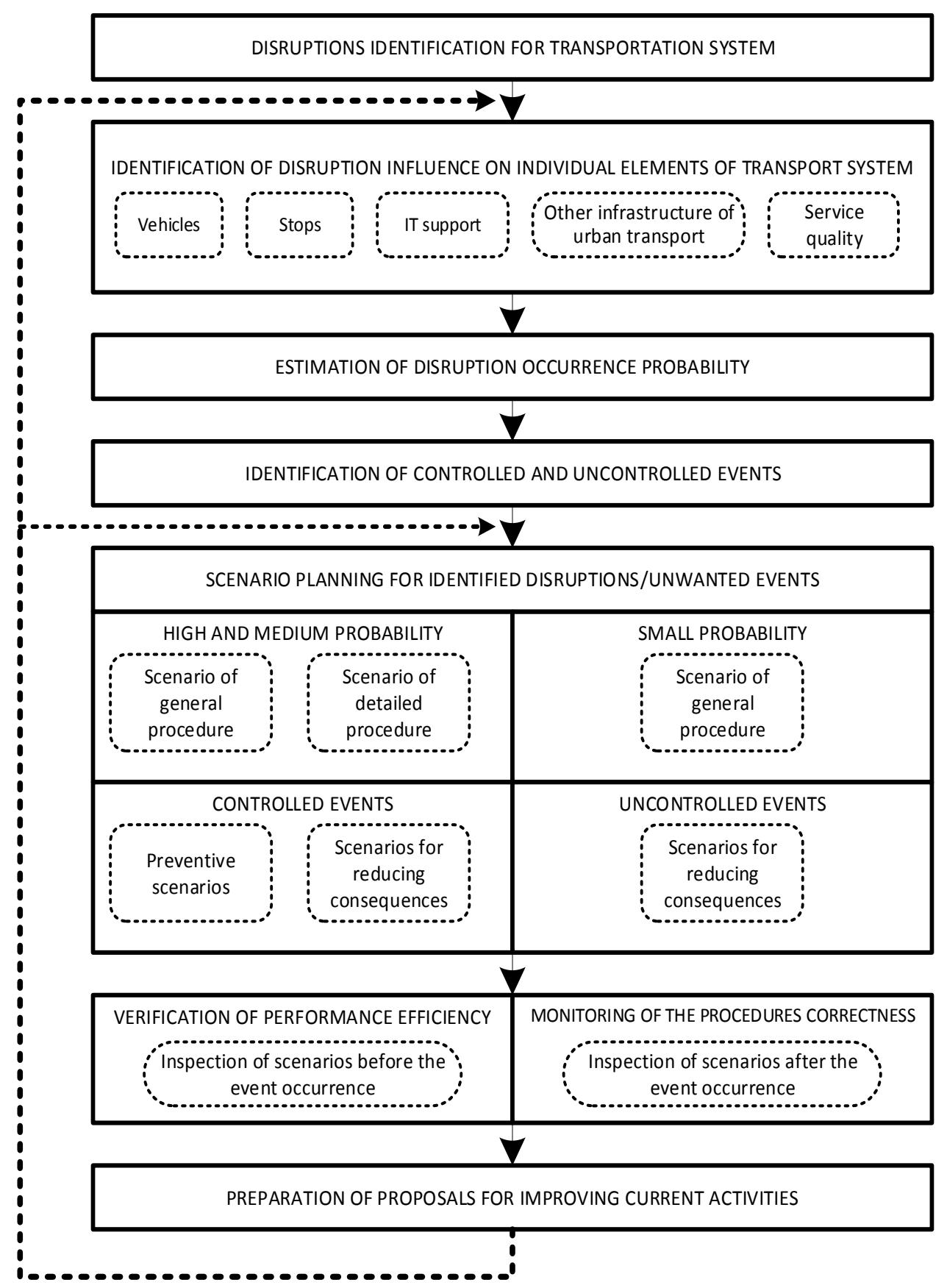

Fig. 1. The analytical procedure within the framework of process controlling 
Based on the classification presented by L. Bukowski [3], there can be proposed the following groups of potential risks defined for public transport performance:

1) External (random):

a. natural treats (winds, storms, flooding)

b. terrorist treats

c. accidents and facility failures

d. street riots

2) External (planned):

a. temporary exclusion of certain streets from the city traffic (repairs, reconstruction, cultural events, marathons)

b. permanent exclusion of certain streets from the urban traffic (changes in the nature of the urban area)

3) Operational:

a. failures in Intelligent Transport Systems performance

b. technical failures of vehicles

c. disturbances in the traction network

d. problems with IT systems supporting the operation of vehicles and the transport services performance

e. problems with the staff (absenteeism, deficiency, strikes)

4) Financial:

a. reducing subsidies from municipalities to fund public transport

b. loss of financial liquidity resulting from the entailing excessive costs (e.g. investments)

5) Logistical:

a. unavailability of spare parts for vehicles in use

b. problems with IT systems supporting operation and maintenance of vehicles (e.g. with the system of warehouse and maintenance)

c. disturbances in cooperation with suppliers of strategic and critical materials

The defined groups of threats being presented above are not an exhaustive list of events that should be analysed by the controller Creation of reference list of all significant threats to the public transport system, according to the adopted classification, is currently the subject of authors' further investigation.

\section{Summary}

In conclusion, it should be underlined that the article is a continuation of our research on the use of the concept of process controlling in passenger transport companies in order to improve the quality of services and to improve the efficiency of their operations. Transport systems vulnerability analysis should be an important element of the predictive and preventive activities done by control staff, supporting operations managers in transport companies. Meanwhile, lot of companies providing passenger transport services, responds "ad hock" for emerging threats, thus facing higher costs for implemented solutions and extending the reaction time to events occurring. 
Issues on vulnerability of passenger transportation system

Zagadnienie podatności na zagrożenia systemu transportu pasażerskiego

The further research are to be focused on the extension of developed analytical procedure, aimed at monitoring the vulnerability of urban transport system and securing the passenger service process performance. As a part of the developed procedure, there is to be created a detailed characteristics of events that could affect the occurrence of disturbances in public transport system.

\section{References}

[1] Balijepalli Ch., Oppong O.: Measuring vulnerability of road network considering the extent of serviceability of critical road links in urban areas, Journal of Transport Geography, 39, 2014, pp. 145-155.

[2] Berdica K.: An introduction to road vulnerability: what has been done, is done and should be done, Transport Policy, 9, 2002, pp. 117-127.

[3] Bukowski L.: Koncepcja modelowania ciągłości procesów logistycznych, Logistyka, 3, 2014, pp.7237-7239.

[4] Cats O., Jenelius E.: Vulnerability analysis of public transport networks: a dynamic approach and case study for Stockholm, W: Proceedings of the $5^{\text {th }}$ International Symposium on Transportation Network Reliability (INSTR2012), 2012, pp.535-544.

[5] Cats O., Jenelius E.: Dynamic vulnerability analysis of public transport networks: mitigation effects of real-time information, Networks and Spatial Economics, 14, 2014, pp. 435-463.

[6] El-Rashidy R. A., Grant-Muller S. M.: An assessment method for highway network vulnerability, Journal of Transport Geography, 34, 2014, pp. 34-43.

[7] Erath A., Birdsall J., Axhausen K. W., Hajdin R.: Vulnerability assessment methodology for Swiss road network, Transportation Research Record: Journal of the Transportation Research Board, 2137, 2009, pp. 118-126.

[8] Haimes Y. Y.: On the definition of vulnerabilities in measuring risks to infrastructures, Risk Analysis, 26, 2, 2006, pp. 293-296.

[9] Jenelius E.: Network structure and travel patterns: Explaining the geographical disparities of road network vulnerability, Journal of Transport Geography, 17, 3, 2009, pp. 234-244.

[10] Jenelius E., Mattsson L-G.: Road network vulnerability analysis of area-covering disruption: a grid-based approach with case study, Transportation Research Part A: Policy and Practice, 46, 5, 2012, pp. 746-760.

[11] Jodejko-Pietruczuk A., Mlynczak M., Zajac M.: Assessment of economical lifetime of heavy-duty machines. Case study, Reliability, Risk and Safety: Theory and applications, vols 1-3, 2010, pp. 531-534.

[12] Johansson J., Hassel H.: An approach for modelling interdependent infrastructures in the context of vulnerability analysis, Reliability Engineering and System Safety, 95, 2010, pp. 1335-1344. 
[13] Khademi N., Balaei B., Shahri M., Mirzaei M., Sarrafi B., Zahabiun M., Mohaymany A. S.: Transportation network vulnerability analysis of the case of a catastrophic earthquake, International Journal of Disaster Risk Reduction, 12, 2015, pp. 234-254.

[14] Kierzkowski A., Kisiel T.: Modelling the passenger flow at an airport terminal to increase the safety level. Proc. of ICMT 2015 - International Conference on Military Technologies 2015, DOI: 10.1109/MILTECHS.2015.7153693.

[15] Kierzkowski A., Kisiel T.: Conception of logistic support model for controlling passengers streams at the Wroclaw Airport . Proc. of PSAM 2014 - Probabilistic Safety Assessment and Management, 2014.

[16] Mattsson L-G., Jenelius E.: Vulnerability and resilience of transport systems a discussion of recent research, Transportation research Part A, 81, 2015, pp. 16-34.

[17] Murray A. T., Matishiw T. C., Grubesic T. H.: A methodological overview of network vulnerability analysis, Growth and Change, 39, 4, 2008, pp. 573-592.

[18] Nowakowski T.: Vulnerability vs. dependability of logistic systems, Proceedings of Carpathian Logistics Congress CLC 2013, 9-11 December 2013, Cracow, Poland.

[19] Nowakowski T.: Vulnerability vs. Dependability and Risk - analysis of the definitions (in Polish), Proceedings of XLI Winter School of Reliability: Dependability of Critical Infrastructures. 6-12 January 2013, Szczyrk, Poland: 13-17.

[20] Nowakowski T., Werbińska-Wojciechowska S.: Problems of logistic systems vulnerability and resilience assessment, In: P. Golinska (ed.), Logistics operations, supply chain management and sustainability. Springer, 2014, pp. 171-186.

[21] Nowakowski T., Valis D.: Selected Options of Vulnerability Assessment - State of Art in Literature Review. Logistics and Transport, 17, 1, 2013, pp. 33-40.

[22] Ouyang M., Pan Z., Hong L., He Y.: Vulnerability analysis of complementary transportation systems with applications to railway and airline systems in China, Reliability Engineering and System Safety, 142, 2015, pp. 248-257.

[23] Ouyang M., Zhao L., Hong L., Pan Z.: Comparisons of complex network based models and real train flow model to analyze Chinese railway vulnerability, Reliability Engineering and System Safety, 123, 2014, pp. 38-46.

[24] Proag V.: The concept of vulnerability and resilience, Procedia Economics and Finance, 18, 2014, pp. 369-376.

[25] Reggiani A., Nijkamp R., Lanzi D.: Transport resilience and vulnerability: the role of connectivity, Transportation Research Part A, 81, 2015, pp. 4-15.

[26] Restel F.J.: Concept of railway transportation system resilience - an introduction. Safety and reliability of complex engineered systems: proceedings of the 25th European Safety and Reliability Conference, ESREL 2015, Zurich, Switzerland, 7-10 September 2015. eds. Luca Podofillini et al.: CRC Press/Balkema, 2015, pp. 565-572.

[27] Rodrigues-Nunez E., Garcia-Palomares J. C.: Measuring the vulnerability of public transport networks, Journal of Transport Geography, 35, 2014, pp. 50-63.

[28] Schoon M.: A short historical overview of the concepts of resilience, vulnerability, and adaptation, Workshop in Political Theory and Policy Analysis Indiana University, Working Paper W05-4, 2005. 
Issues on vulnerability of passenger transportation system

Zagadnienie podatności na zagrożenia systemu transportu pasażerskiego

[29] Sullivan J. L., Aultman-Hall L., Novak D. C.: A review of current practice in network disruption analysis and an assessment of the ability to account for isolating links in transportation networks, Transportation Letters: The International Journal of Transportation Research, 1 4, 2009, pp. 271-280.

[30] Tarapata Z., Mierzejewski K.: Prognozowanie i symulacja skutków wystąienia zagrożeń systemu komunikacyjnego aglomeracji, Symulacja w Badaniach i Rozwoju, 1, 1, 2010, pp. 93-106.

[31] Taylor M. A. P., D’Este G. M.: Transport network vulnerability: a method for diagnosis of critical locations in transport infrastructure systems, In: Murray A. T., Grubesic T. H. (ed.): Critical Infrastructure. Reliability and Vulnerability, Springer, 2007.

[32] Tixier J., Tena-Chollet F., Dusserre G., Lapebie E., Munier L., Osmont A.: Development of a GIS-based approach for the vulnerability assessment of a territory exposed to a potential risk, Proceedings of the 43rd ESReDA Seminar on land use planning and risk-informed decision making. Saint-Étienne-du Rouvray, France, Oct 22-23, 2012.

[33] Valis D., Vintr Z., Malach J.: Selected aspects of physical structures vulnerability - state-of-the-art, Eksploatacja i Niezawodnosc - Maintenance and Reliability, 14, 3, 2012, pp. 189-194.

[34] Waita Njogu H., Jiawei L., Kiere J. N., Hanyurwimfura D.: A comprehensive vulnerability based alert management approach for large networks, Future Generation Computer Systems, 29, 2013, pp. 27-45.

[35] Wang Z., Chan A. P., Yuan J., Xia B., Skitmore M., Li Q.: Recent advances in modelling the vulnerability of transportation networks, Journal of Infrastructure Systems, 21, 2, 2015.

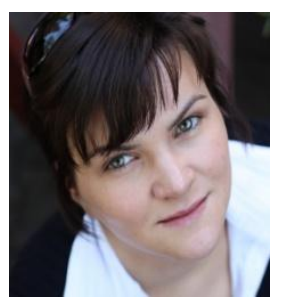

Agnieszka Tubis Ph.D. Wroclaw University of Technology, Faculty of Mechanical Engineering, Department of Maintenance and Operation of Logistic, Transportation and Hydraulic Systems. PhD Dissertation concerned the cooperation of manufacturers and retailers in the area of planning, forecasting and replenishment according to the concept of CPFR. Current interests are connected with the concept of process controlling being implemented in the maintenance and operations management of vehicles and she is interests in systems that support decision-making processes of managers in the road transport companies. (Share: 50\%).

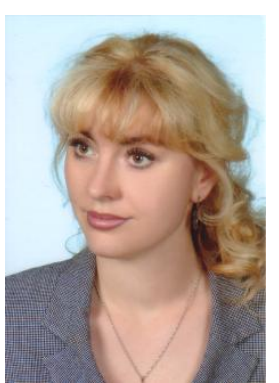

Sylwia Werbińska-Wojciechowska Ph.D. Eng. Wroclaw University of Technology, Faculty of Mechanical Engineering, Department of Maintenance and Operation of Logistic, Transportation and Hydraulic Systems; PhD Dissertation investigated the modelling issues of logistics systems that support technical systems maintenance and operation processes; current interests are related to the issues of technical systems maintenance modelling with the use of time-delay concept, modeling and performance measurement of transport systems operation, and supply chains resilience and vulnerability problems. (Share: 50\%). 


\section{ZAGADNIENIE PODATNOŚCI NA ZAGROŻENIA SYSTEMU TRANSPORTU PASAŻERSKIEGO}

\section{Wstęp}

Systemy transportowe pełnią istotną rolę $\mathrm{w}$ społeczeństwie, wspierając funkcjonowanie nowoczesnej gospodarki oraz realizując usługi transportowe dla szerokiego grona pasażerów $[5,15,22]$. Jednakże, systemy te narażone są na pewne zdarzenia niepożądane, jak np. pojawienie się zakłóceń w wyniku zdarzeń losowych (np. katastrofy naturalne), starzenie się obiektów technicznych, zmiany popytu, zmiany klimatu, czy zagrożenia terrorystyczne [23]. Zdarzenia te zwiększają podatność danych systemów na zagrożenia (ang. vulnerability), co może prowadzić do pojawienia się negatywnych konsekwencji dla ludzi i organizacji m.in. w aspekcie ekonomicznym, bezpieczeństwa, czy zdrowia [12]. Obecnie poziom uzależnienia społeczeństwa od realizacji niezawodnej usługi transportowej rośnie, przez co takie zagadnienia jak podatność na uszkodzenia, czy zarząadzanie ryzykiem zyskują na znaczeniu (np. [2, 12, 14, 22]). W świetle idei zrównoważonego transportu, gdzie system transportowy powinien cechować się dostępnością, wysoką jakością i bezpieczeństwem oferowanych usług, czy przyjaznością dla środowiska, właściwie przeprowadzone analizy ryzyka oraz oceny podatności na zagrożenia stanowią fundament $\mathrm{w}$ procesie kontroli potencjalnego ryzyka oraz przy podejmowaniu decyzji odnośnie redukcji jego poziomu [11, 12].

Dlatego też, w artykule skupiono się na zagadnieniu oceny podatności na zagrożenia drogowego systemu transportu pasażerskiego. Celem artykułu jest przedstawienie tego zagadnienia jako elementu analiz przeprowadzanych w ramach controllingu procesowego, dostosowanego do potrzeb przedsiębiorstwa świadczącego usługi przewozu w ramach komunikacji miejskiej. W związku z tym, w kolejnym punkcie przedstawiono przegląd literatury $\mathrm{z}$ obszaru podatności na zagrożenia systemów transportowych. Następnie skupiono się na zagadnieniach oceny podatności na zagrożenia danych systemów. Pozwoliło to, przeprowadzić grupowanie potencjalnych zdarzeń stanowiących zagrożenie dla systemu komunikacji miejskiej. Przedstawiono również schemat postępowania oceniającego podatność na zagrożenia, przeprowadzanego zgodnie z controllingową koncepcją sprzężenia zwrotnego. Artykuł kończy podsumowanie oraz wytyczne obejmujące kierunki dalszych badań.

\section{Podatność na zagrożenia systemów transportowych - przegląd literatury}

Obecnie istnieje bardzo wiele prac obejmujących zagadnienia podatności na zagrożenia systemów technicznych (infrastruktury krytycznej, systemów transportowych, itp.). Jednocześnie, samo pojęcie podatności na zagrożenia jest definiowane $\mathrm{w}$ różny sposób, $\mathrm{w}$ zależności m.in. od obszaru badawczego, czy wykorzystywanych przez autorów metod badawczych. 
Issues on vulnerability of passenger transportation system

Zagadnienie podatności na zagrożenia systemu transportu pasażerskiego

W pracy [28] autor zebrał i przedstawił znane w literaturze definicje pojęć: podatności na zagrożenia, odporności systemów na zagrożenia oraz koncepcji adaptacji do zmieniających się warunków. Ponadto omówił historię rozwoju danych pojęć. Następnie, autor $\mathrm{w}$ pracy [8] analizował pojęcie podatności na zagrożenia $\mathrm{w}$ aspekcie pomiaru i oceny ryzyka funkcjonujących systemów. Z kolei autorzy pracy [12] przedstawili trzy perspektywy analizy podatności na zagrożenia systemów technicznych - podejście do oceny podatności na zagrożenia systemu globalnego, ocenę podatności na zagrożenia elementu systemu, oraz badanie systemu pod kątem lokalizacji geograficznej jego elementów i jej wpływu na poziom podatności na zagrożenia. Zaproponowany model oceny podatności na zagrożenia został zaimplementowany w obszarze funkcjonowania sieci kolejowej zelektryfikowanej.

W kolejnej pracy [32], autorzy przedstawili trzydzieści siedem definicji pojęcia podatności na zagrożenia w zależności od obszaru badawczego.

Jednocześnie, przegląd literatury dotyczącej zagadnienia podatności na zagrożenia systemów technicznych, w tym próby definicji tego pojęcia również w odniesieniu do ryzyka, czy niezawodności przedstawiono m.in. w pracach $[18,19,20,21,24$, 26, 31, 33].

Pojęcie podatności na zagrożenia systemów transportowych jest w literaturze analizowane wieloaspektowo, przez co nie ma jednej definicji powszechnie uznanej za właściwą [16]. Pierwszą pracą, która przedstawiała koncepcję oceny podatności na zagrożenia w obszarze funkcjonowania systemów transportowych (proponując formalne podstawy) jest [2]. Autorka w swojej pracy zaproponowała definicję podatności na zagrożenia systemu transportu drogowego jako jego podatności na incydenty, które moga $w$ rezultacie przetożyć się na redukcje zdolności użytkowej (serviceability) sieci drogowej. Definicja ta jest obecnie szeroko cytowana w literaturze i traktowana jako reprezentatywna dla większości rodzajów transportu [16].

Inne podejście do definicji podatności na zagrożenia odnosi się do miary prawdopodobieństwa wystąpienia zdarzenia oraz pojawiających się konsekwencji zdarzenia/krytyczności elementów (np. prace [7,9, 12). Z kolei trzeci sposób interpretacji definicji podatności systemu transportowego na zagrożenia przyrównuje ją do tzw. pięty Achillesa [35].

W tabeli 1 przedstawiono przykładowe definicje podatności na zagrożenia systemów transportowych, proponowane w najnowszej literaturze. Pewne podsumowanie literatury $\mathrm{z}$ obszaru definicji pojęcia podatności na zagrożenia proponowane jest m.in. $w$ pracy [25], gdzie autorzy przedstawiają przegląd literatury m.in. pod kątem struktury przeprowadzanych analiz, sposobu interpretacji i pomiaru, czy publikowanych modeli symulacyjnych i studiów przypadków. Ponadto w pracy [16] autorzy omawiają przegląd literatury $\mathrm{w}$ zakresie oceny podatności na zagrożenia oraz odporności na zagrożenia systemów transportowych. 
Tabela 1. Wybrane definicje podatności na zagrożenia system transportowego

\begin{tabular}{|c|l|}
\hline Źródło & \multicolumn{1}{|c|}{ Definicja } \\
\hline$[2]$ & podatność na rzadkie, duże rzeczy \\
\hline$[7]$ & $\begin{array}{l}\text { wyrażone przez prawdopodobieństwo że } i \text {-ty komponent uszkodzi się } \\
\text { w czasie w wyniku wystąpienia zdarzenia niepożądanego oraz sumy } \\
\text { kosztów bezpośrednich i pośrednich wynikających z tego zdarzenia }\end{array}$ \\
\hline$[10]$ & $\begin{array}{l}\text { społeczne ryzyko wystąpienia zakłócen oraz procesu degradacji } \\
\text { w systemie transportowym }\end{array}$ \\
\hline$[22]$ & $\begin{array}{l}\text { spadek poziomu funkcjonowania z powodu wystąpienia zdarzenia } \\
\text { niepożądanego/uciążliwego }\end{array}$ \\
\hline$[31]$ & $\begin{array}{l}\text { węzeł sieci jest podatny na zagrożenia w przypadku gdy utrata lub istotna } \\
\text { degradacja niewielkiej liczby połączeń znacznie zmniejszają dostępność } \\
\text { węzła, mierzoną przez standardowy wskaźnik dostępności }\end{array}$ \\
\hline$[34]$ & $\begin{array}{l}\text { wada lub słaby punkt w systemie, które mogą zostać wykorzystane przez } \\
\text { intruzów }\end{array}$ \\
\hline
\end{tabular}

Obecnie w literaturze można znaleźć szereg metod oraz wskaźników oceny podatności na zagrożenia systemów transportowych - głównie sieci transportowych (np. prace $[2,6,9,27,31]$ ). Przegląd i analizę wykorzystywanych w literaturze metod oceny i analizy podatności na zagrożenia infrastruktur sieciowych przedstawiono m.in. w pracach [13, 16, 17, 29]. W pracy [17] zaproponowano klasyfikację wykorzystywanych w praktyce metod, proponując grupy obejmujące modelowanie matematyczne, modele symulacyjne, modele scenariuszowe, bazujące na analizie scenariuszy potencjalnego zakłócenia i wykorzystujące metody jakościowe, oraz modele bazujące na podejściu definicji strategii postępowania podczas wystąpienia zakłócenia. Z kolei w pracy [29] autorzy przedstawili przegląd literatury obejmującej metody analizy zakłóceń sieci transportowych. Natomiast autorzy pracy [16] przedstawili przegląd literatury z obszaru podatności na zagrożenia oraz odporności na zagrożenia systemów transportowych. Przedyskutowano m.in. metody bazujące na wykorzystaniu teorii grafów, czy podejścia systemowego.

Autorzy pracy [13], bazując na szerokim przeglądzie literatury, zaproponowali metodologię analizy podatności na zagrożenia miejskiej sieci transportowej w świetle zagrożenia wystąpieniem trzęsienia ziemi.

Z kolei autorzy pracy [22] klasyfikują metody wykorzystywane w obszarze analizy podatności na zagrożenia systemów transportowych do jednej $\mathrm{z}$ dwóch grup: bazujących na podejściu sieciowym oraz na podejściu topologicznym.

Ponadto w literaturze można znaleźć prace uwzględniające dynamiczny charakter funkcjonowania sieci transportowych. Przykładowo w pracy [4] autorzy zaproponowali model dynamiczny oceny funkcjonowania sieci transportowej $\mathrm{z}$ uwzględnieniem niepewności funkcjonowania transportu publicznego, jak np. natężenie ruchu, pojemność pojazdów, czy zakłócenia w realizacji usług transportowych. 
Issues on vulnerability of passenger transportation system

Zagadnienie podatności na zagrożenia systemu transportu pasażerskiego

Model bazował na wykorzystaniu teorii grafów oraz modelu zwanego BuzzMezzo, służącego do modelowania dynamicznego m.in. zadań transportowych (ang. dynamic transit operations and assignment model). Problem modelowania dynamicznego był później kontynuowany w pracy [5].

Natomiast prace, w których skupiono się na zaproponowaniu pewnych miar oceny podatności na zagrożenia systemów transportowych to m.in. [1, 6, 35], gdzie autorzy zaproponowali pewne wskaźniki oceny (vulnerability index) przede wszystkim uwzględniając podejścia bazujące na pomiarze kosztów oraz odległości pomiędzy punktami sieci transportowej. Klasyfikację wskaźników oceny podatności sieci transportowej na zagrożenia zaproponowano w pracy [35].

Podsumowując, obecnie publikowane prace z zakresu oceny i analizy podatności systemów transportowych na zagrożenia skupiają się przede wszystkim na badaniu funkcjonowania sieci transportowych w sytuacji występowania zakłócenia ich węzłów. Brakuje prac, które opisywałyby problem oceny podatności na zagrożenia systemów transportowych jako elementu predykcji, realizowanej $\mathrm{w}$ ramach systemu controllingu procesowego, którego zadaniem jest czuwania nad poprawnością procesu obsługi pasażerów.

\section{Zagadnienia oceny podatności na zagrożenia systemów transportowych jako element analiz controllingu procesowego}

Bardzo popularnym podejściem $\mathrm{w}$ literaturze jest traktowanie podatności na zagrożenia systemów transportowych $\mathrm{w}$ kategoriach prawdopodobieństwa wystąpienia zagrożenia/zakłócenia oraz jego konsekwencji [35]. Bazując na tym podejściu, podczas analizy podatności na zagrożenia sieci transportowej zadawane są trzy podstawowe pytania [35]:

- Czy jest słaby punkt lub lokalizacja geograficzna, których zakłócenie może powodować poważne zakłócenie funkcjonowania systemu?

- Jak podatna na zagrożenia jest sieć gdy komponenty krytyczne ulegną zakłóceniu/uszkodzeniu?

- Na jakiego typu uszkodzenia/zakłócenia sieć transportowa jest podatna?

Odpowiedź na dane pytania wymaga określenia typu zdarzeń, które potencjalnie mogą zakłócić $\mathrm{w}$ znacznym stopniu funkcjonowanie systemu transportowego. W oparciu o pracę [2], zdarzenia takie dla systemu transportu drogowego można zaklasyfikować do trzech grup: zdarzeń nagłych i/lub o nieprzewidywalnej naturze (np. pogoda, wypadki drogowe, uszkodzenia infrastruktury i pojazdów), planowanych (np. planowe prace drogowe), oraz zdarzeń zamierzonych (np. ataki terrorystyczne). Z kolei w pracy [30] autorzy zdefiniowali trzy kategorie zagrożeń systemu komunikacyjnego aglomeracji - awarie urządzeń i elementów systemu transportowego, katastrofy i utrudnienia komunikacyjne wywołane przez człowieka, oraz zagrożenia ekologiczne. Natomiast autorzy pracy [16] proponują podział zakłócen $\mathrm{W}$ systemie transportowym $\mathrm{w}$ kategoriach zakłócenie wewnętrzne/zewnętrzne vs. zakłócenie przypadkowe/celowe. 


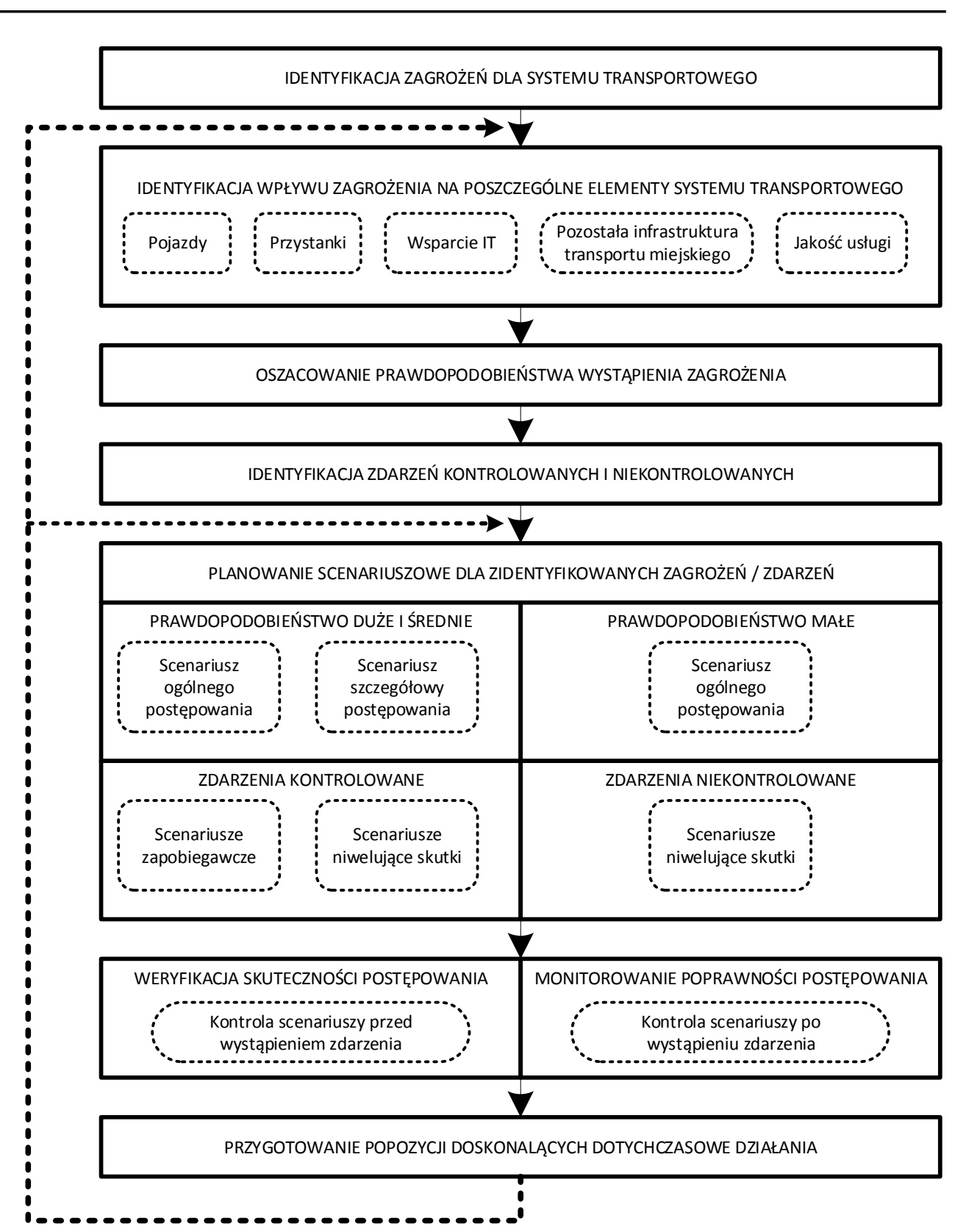

Rys. 1. Postepowanie analityczne $w$ ramach controllingu procesowego

Przedmiotem zainteresowania autorów jest zastosowanie oceny podatności na zagrożenia dla systemu transportu publicznego w dużych aglomeracjach w Polsce. Ocena ta stanowić powinna element postępowania $w$ ramach controllingu procesowego, implementowanego u przewoźnika świadczącego usługi komunikacji miejskiej. 
Issues on vulnerability of passenger transportation system Zagadnienie podatności na zagrożenia systemu transportu pasażerskiego

$\mathrm{Na}$ podstawie przeprowadzonego postępowania, controller powinien móc dostarczyć zarządzającym kompleksowej informacji o możliwych zagrożeniach, ich wpływu na działalność przedsiębiorstwa oraz powinien przygotować propozycje scenariuszy postępowania na wypadek wystąpienia wybranych zagrożeń. Postępowanie analityczne powinno przy tym przebiegać w zgodnie ze schematem przedstawionym na rysunku 1 .

Nadrzędnym celem jest przy tym zidentyfikowanie typów zakłóceń, na które sieć transportowa będzie podatna. Bazując na klasyfikacji przedstawionej przez L. Bukowskiego [3] proponuje się wyróżnić następujące grupy potencjalnych zagrożeń definiowanych dla komunikacji miejskiej:

1) Zewnętrzne (losowe):

a. zagrożenia naturalne (wichury, nawałnice, podtopienia);

b. zagrożenia terrorystyczne;

c. wypadki i awarie;

d. zamieszki uliczne.

2) Zewnętrzne (planowane):

a. czasowe wyłączenia określonych ulic $\mathrm{z}$ ruchu miejskiego (remonty, naprawy, przebudowy, wydarzenia kulturowe, biegi miejskie);

b. trwałe wyłączenia określonych ulic z ruchu miejskiego (zmiana charakteru danej strefy miejskiej).

3) Operacyjne:
a. błędy w funkcjonowaniu ITS;
b. usterki techniczne pojazdów;
c. zakłócenia w sieci trakcyjnej;
d. problemy z systemami IT wspierającymi funkcjonowanie pojazdów oraz realizację usług przewozowych;
e. problemy z kadrą (absencja, niedobory, strajki).

4) Finansowe:

a. ograniczenie dotacji z gminy na finansowanie transportu publicznego;

b. utrata płynności finansowej wynikająca z ponoszenia nadmiernych kosztów (np. inwestycyjnych).

5) Logistyczne:
a. brak dostępności części zamiennych do użytkowanych pojazdów;
b. problemy z systemami IT wspierającymi obsługę i utrzymanie pojazdów (np. system magazynowo-remontowy);
c. zakłócenia we współpracy $\mathrm{z}$ dostawcami materiałów strategicznych i krytycznych.

Przedstawione podgrupy zagrożeń zdefiniowane powyżej nie stanowią pełnej listy zdarzeń, które powinny być przedmiotem analizy controllera. Stworzenie wzorcowego zestawienia wszystkich istotnych zagrożeń dla systemu komunikacji miejskiej, według przyjętej klasyfikacji, jest obecnie przedmiotem dalszych badań autorek. 


\section{Podsumowanie}

Podsumowując, należy zauważyć, iż artykuł jest kontynuacją prac badań autorów nad wykorzystaniem koncepcji controllingu procesowego $\mathrm{W}$ przedsiębiorstwach przewozów pasażerskich, w celu doskonalenia jakości świadczonych usług oraz poprawy efektywności prowadzonej działalności. Analiza podatności systemów transportowych na zagrożenia powinna stanowić istotny element działalności predykcyjnej i prewencyjnej controllerów, wspierających działalność menedżerów w firmach transportowych. Tymczasem wiele przedsiębiorstw świadczących usługi przewozów pasażerskich, reaguje „ad hock” na pojawiające się zagrożenia, ponosząc tym samym wyższe nakłady na wdrażane rozwiązania oraz wydłużając czas reakcji na występujące zdarzenia.

Przedmiotem dalszych badań autorów będzie rozwój przedstawionego modelu postępowania analitycznego, ukierunkowanego na monitorowanie podatności systemu transportu miejskiego na zagrożenia oraz zabezpieczanie ciągłości procesu obsługi pasażerów. W ramach tworzonego postępowania analitycznego stworzona zostanie również wzorcowa charakterystyka szczegółowa zdarzeń mogących wpływać na występowanie zakłóceń w systemie komunikacji miejskiej.

\section{Literatura}

[1] Balijepalli Ch., Oppong O.: Measuring vulnerability of road network considering the extent of serviceability of critical road links in urban areas, Journal of Transport Geography, 39, 2014, pp. 145-155.

[2] Berdica K.: An introduction to road vulnerability: what has been done, is done and should be done, Transport Policy, 9, 2002, pp. 117-127.

[3] Bukowski L.: Koncepcja modelowania ciągłości procesów logistycznych, Logistyka, 3, 2014, pp.7237-7239.

[4] Cats O., Jenelius E.: Vulnerability analysis of public transport networks: a dynamic approach and case study for Stockholm, W: Proceedings of the $5^{\text {th }}$ International Symposium on Transportation Network Reliability (INSTR2012), 2012, pp.535-544.

[5] Cats O., Jenelius E.: Dynamic vulnerability analysis of public transport networks: mitigation effects of real-time information, Networks and Spatial Economics, 14, 2014, pp. 435-463.

[6] El-Rashidy R. A., Grant-Muller S. M.: An assessment method for highway network vulnerability, Journal of Transport Geography, 34, 2014, pp. 34-43.

[7] Erath A., Birdsall J., Axhausen K. W., Hajdin R.: Vulnerability assessment methodology for Swiss road network, Transportation Research Record: Journal of the Transportation Research Board, 2137, 2009, pp. 118-126. 
Issues on vulnerability of passenger transportation system

Zagadnienie podatności na zagrożenia systemu transportu pasażerskiego

[8] Haimes Y. Y.: On the definition of vulnerabilities in measuring risks to infrastructures, Risk Analysis, 26, 2, 2006, pp. 293-296.

[9] Jenelius E.: Network structure and travel patterns: Explaining the geographical disparities of road network vulnerability, Journal of Transport Geography, 17, 3, 2009, pp. 234-244.

[10] Jenelius E., Mattsson L-G.: Road network vulnerability analysis of area-covering disruption: a grid-based approach with case study, Transportation Research Part A: Policy and Practice, 46, 5, 2012, pp. 746-760.

[11] Jodejko-Pietruczuk A., Mlynczak M., Zajac M.: Assessment of economical lifetime of heavy-duty machines. Case study, Reliability, Risk and Safety: Theory and applications, vols 1-3, 2010, pp. 531-534.

[12] Johansson J., Hassel H.: An approach for modelling interdependent infrastructures in the context of vulnerability analysis, Reliability Engineering and System Safety, 95, 2010, pp. 1335-1344.

[13] Khademi N., Balaei B., Shahri M., Mirzaei M., Sarrafi B., Zahabiun M., Mohaymany A. S.: Transportation network vulnerability analysis of the case of a catastrophic earthquake, International Journal of Disaster Risk Reduction, 12, 2015, pp. 234-254.

[14] Kierzkowski A., Kisiel T.: Modelling the passenger flow at an airport terminal to increase the safety level. Proc. of ICMT 2015 - International Conference on Military Technologies 2015, DOI: 10.1109/MILTECHS.2015.7153693.

[15] Kierzkowski A., Kisiel T.: Conception of logistic support model for controlling passengers streams at the Wroclaw Airport . Proc. of PSAM 2014 - Probabilistic Safety Assessment and Management, 2014.

[16] Mattsson L-G., Jenelius E.: Vulnerability and resilience of transport systems a discussion of recent research, Transportation research Part A, 81, 2015, pp. 16-34.

[17] Murray A. T., Matishiw T. C., Grubesic T. H.: A methodological overview of network vulnerability analysis, Growth and Change, 39, 4, 2008, pp. 573-592.

[18] Nowakowski T.: Vulnerability vs. dependability of logistic systems, Proceedings of Carpathian Logistics Congress CLC 2013, 9-11 December 2013, Cracow, Poland.

[19] Nowakowski T.: Vulnerability vs. Dependability and Risk - analysis of the definitions (in Polish), Proceedings of XLI Winter School of Reliability: Dependability of Critical Infrastructures. 6-12 January 2013, Szczyrk, Poland: 13-17.

[20] Nowakowski T., Werbińska-Wojciechowska S.: Problems of logistic systems vulnerability and resilience assessment, In: P. Golinska (ed.), Logistics operations, supply chain management and sustainability. Springer, 2014, pp. 171-186.

[21] Nowakowski T., Valis D.: Selected Options of Vulnerability Assessment - State of Art in Literature Review. Logistics and Transport, 17, 1, 2013, pp. 33-40. 
[22] Ouyang M., Pan Z., Hong L., He Y.: Vulnerability analysis of complementary transportation systems with applications to railway and airline systems in China, Reliability Engineering and System Safety, 142, 2015, pp. 248-257.

[23] Ouyang M., Zhao L., Hong L., Pan Z.: Comparisons of complex network based models and real train flow model to analyze Chinese railway vulnerability, Reliability Engineering and System Safety, 123, 2014, pp. 38-46.

[24] Proag V.: The concept of vulnerability and resilience, Procedia Economics and Finance, 18, 2014, pp. 369-376.

[25] Reggiani A., Nijkamp R., Lanzi D.: Transport resilience and vulnerability: the role of connectivity, Transportation Research Part A, 81, 2015, pp. 4-15.

[26] Restel F.J.: Concept of railway transportation system resilience - an introduction. Safety and reliability of complex engineered systems: proceedings of the 25th European Safety and Reliability Conference, ESREL 2015, Zurich, Switzerland, 7-10 September 2015. eds. Luca Podofillini et al.: CRC Press/Balkema, 2015, pp. 565-572.

[27] Rodrigues-Nunez E., Garcia-Palomares J. C.: Measuring the vulnerability of public transport networks, Journal of Transport Geography, 35, 2014, pp. 50-63.

[28] Schoon M.: A short historical overview of the concepts of resilience, vulnerability, and adaptation, Workshop in Political Theory and Policy Analysis Indiana University, Working Paper W05-4, 2005.

[29] Sullivan J. L., Aultman-Hall L., Novak D. C.: A review of current practice in network disruption analysis and an assessment of the ability to account for isolating links in transportation networks, Transportation Letters: The International Journal of Transportation Research, 1 ,4, 2009, pp. 271-280.

[30] Tarapata Z., Mierzejewski K.: Prognozowanie i symulacja skutków wystąpienia zagrożeń systemu komunikacyjnego aglomeracji, Symulacja w Badaniach i Rozwoju, 1, 1, 2010, pp. 93-106.

[31] Taylor M. A. P., D’Este G. M.: Transport network vulnerability: a method for diagnosis of critical locations in transport infrastructure systems, In: Murray A. T., Grubesic T. H. (ed.): Critical Infrastructure. Reliability and Vulnerability, Springer, 2007.

[32] Tixier J., Tena-Chollet F., Dusserre G., Lapebie E., Munier L., Osmont A.: Development of a GIS-based approach for the vulnerability assessment of a territory exposed to a potential risk, Proceedings of the 43rd ESReDA Seminar on land use planning and risk-informed decision making. Saint-Étienne-du Rouvray, France, Oct 22-23, 2012.

[33] Valis D., Vintr Z., Malach J.: Selected aspects of physical structures vulnerability - state-of-the-art, Eksploatacja i Niezawodnosc - Maintenance and Reliability, 14, 3, 2012, pp. 189-194. 
Issues on vulnerability of passenger transportation system Zagadnienie podatności na zagrożenia systemu transportu pasażerskiego

[34] Waita Njogu H., Jiawei L., Kiere J. N., Hanyurwimfura D.: A comprehensive vulnerability based alert management approach for large networks, Future Generation Computer Systems, 29, 2013, pp. 27-45.

[35] Wang Z., Chan A. P., Yuan J., Xia B., Skitmore M., Li Q.: Recent advances in modelling the vulnerability of transportation networks, Journal of Infrastructure Systems, 21, 2, 2015.

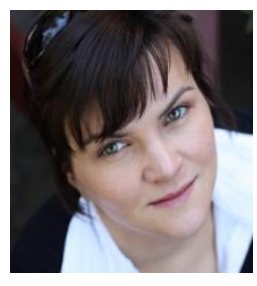

dr Agnieszka Tubis, Politechnika Wroctawska, Wydziat Mechaniczny, Katedra Eksploatacji Systemów Logistycznych, Systemów Transportowych $i$ Uktadów Hydraulicznych. Rozprawa doktorska dotyczyta wspótpracy producentów i sieci handlowych $w$ obszarze planowania, prognozowania $i$ uzupetniania zapasów wg koncepcji CPFR. Obecne zainteresowania zwiazane sa $z$ koncepcja controllingu procesowego implementowanego $w$ obszarze zarzadzania eksploatacja pojazdów oraz systemami doradczymi wspierajacymi procesy decyzyjne kadry menedżerskiej $w$ przedsiębiorstwach transportu drogowego. (Udziat:50\%).

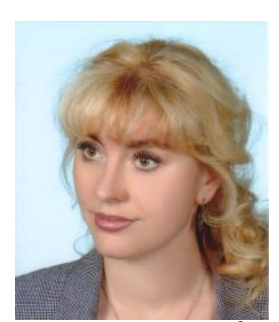

dr inż. Sylwia Werbińska-Wojciechowska, Politechnika Wroctawska, Wydziat Mechaniczny, Katedra Eksploatacji Systemów Logistycznych, Systemów Transportowych i Układów Hydraulicznych; Rozprawa doktorska obejmowała problematyke modelowania wsparcia logistycznego procesów eksploatacji systemów technicznych; obecnie zainteresowania zwiazane sa z zagadnieniami modelowania strategii utrzymania systemów technicznych z wykorzystaniem koncepcji opóźnień czasowych, modelowania i oceny funkcjonowania systemów transportowych oraz problemów oceny odporności na zagrożenia tańcuchów dostaw. (Udziat: 50\%). 